\title{
THE APPARENT DEGENERATION OF PINEAPPLE SLIPS IN PUERTO RICO
}

\section{Ernesto Hernández-Medina ${ }^{1}$}

\section{INTRODUCTION}

One of the problems with which the pineapple growers of Puerto Rico are confronted and which merits immediate attention and solution is that of a decline in vigor of pineapple slips which lowers yields. Pineapple growers complain about the difficulty they encounter after about twoplant generations in obtaining pineapple slips of proper planting size. They attribute this to a decline in vigor or "run-down" which is said to occur when Red Spanish slips originally obtained from Cuba are grown in Puerto Rico for about two generations. The condition is serious, as it lowers yields sufficiently to menace the economic status of the pineapple growers who are obliged to import slips from Cuba, and that is expensive.

Late information obtained from Cuba by Mr. Héctor Gandía, who made a trip there last year to procure slips for Puerto Rican pineapple growers, indicates that the slips are apparently also "degenerating" there. If such is the case the problem of getting slips from Cuba will worsen in the future. Under these circumstances immediate action should be taken to find the cause of this loss of vigor or apparent "degeneration" and to devise means of improving our native stock so as to increase fruit production.

As an index of the seriousness of the problem, recent information $(1)^{2}$ indicates that production of pineapples for the 1951 crop (average plant and ratoon) amounted to 27,700 tons of fruit harvested on 3,050 cuerdas, or only 9.2 tons of fruit per cuerda. ${ }^{3}$ This yield is considered relatively low for Puerto Rico.

Suggestions $(4,14,15,16)$ had been made that the so-called degeneration of pineapple slips might result from a nutritional derangement in the plant produced by an unfavorable balance between iron and manganese, and that this disturbance was perhaps of a more severe nature in plants developed from native ${ }^{4}$ than in those developed from Cuban slips. ${ }^{5}$ This

${ }^{1}$ Assistant Plant Physiologist, Agricultural Experiment Station, University of Puerto Rico, Río Piedras, Puerto Rico. The author wishes to express his appreciation to Mrs. Olga E. Vega de Rivera for technical help in part of the analyses of the leaftissue fractions and to Dr. B. G. Capó and Mr. Ishver S. Bangdiwala for their cooperation in the statistical analyses.

2 Numbers in parentheses refer to Literature Cited, p. 317.

${ }^{3} \mathrm{~A}$ cuerda $=0.97$ acre

${ }^{4}$ Native slips-slips of plants developed in Puerto Rico although planted originally with Cuban slips.

${ }^{5}$ Cuban slips-slips brought from Cuba and planted for the first time in Puerto Rico. 
led the author to study the iron-manganese relationships in the pineapple plant under field conditions as the initial point of attack of this problem.

The yellowing of pineapple plants has been correlated with the presence of abnormally large quantities of manganese in the soil $(8,17)$. Later work carried out by Johnson $(5,6,7)$ with yellow pineapple plants indicated that the assimilation of iron in these plants was depressed in manganiferous soils. From this, it may be inferred that the plants developed chlorosis from lack of sufficient metabolically active iron for normal chlorophyll synthesis. Since chlorosis developed earlier and to a more marked extent in the pineapple plants from native slips than in those from Cuban slips, manganese was assumed to be the main cause of such abnormal plant metabolism.

\section{Experimental Methods}

CULTURAL

With the objective mentioned, two pineapple field experiments were undertaken in the fall of 1946 . The first of these was started on November 21, 1946, in the area of Palo Blanco, Arecibo, in Bayamón silty clay which had been in continuous pineapple cultivation for about 20 years. The $\mathrm{pH}$ of this soil was 4.94, indicating that it was relatively acid.

The second pineapple experiment was started on December 5, 1946, at the Experiment Station Farm in Fajardo clay. This soil had an average $\mathrm{pH}$ of 5.04, thus also being relatively acid. It had been in pasture for several years and never in pineapples.

Pineapple slips obtained directly from Cuba and native slips from a second generation were used in both experiments. The experiments followed a randomized block arrangement. Each group of pineapple slips underwent 4 different treatments, each treatment being repeated 5 times in plots of $1 / 27_{2} \mathrm{~A}$. Each plot contained 45 slips, or a total of 225 per treatment. The treatments tried in both groups of pineapple slips or plants were as follows: 1 , soil treated with calcium carbonate to raise its $\mathrm{pH}$ to 6.2 , plus 2 iron sprays to plants; 2 , soil treated with calcium carbonate to raise its $\mathrm{pH}$ to 6.2 , plus 4 iron sprays to plants; 3 , untreated soil plus 2 iron sprays to plants; and 4, untreated soil plus 4 iron sprays to plants.

The lime necessary to raise the soil $\mathrm{pH}$ to the required value was determined according to the method of Riera (11). The Arecibo soil required 3 tons of limestone per acre while the Río Piedras soil required 6 tons to raise the soil $\mathrm{pH}$ to 6.2. This indicates that the Río Piedras soil had a higher buffer capacity than the Arecibo soil, since the original $\mathrm{pH}$ of both was practically the same, about 5 . The lime was incorporated with the top 6 inches of soil. The iron sprays consisted in applying to the plants a 
solution of ferrous sulfate made by dissolving 25 pounds of the salt in 100 gallons of water.

The pineapple plants received fertilizer, formula $10^{6}-6-9$, at the rate of $11 / 2$ tons per acre. The fertilizer mixture was distributed in 4 applications during the growth period of the plants as is usual in commercial plantings.

To force blooming, the pineapple plants of the Arecibo experiment were acetylene treated on January 30, 1948, 14 months after planting, while those of the Río Piedras experiment received their acetylene treatment on February 12, 1948, also 14 months after planting. The experiments were harvested on June and July 1948, respectively.

Leaf samples were taken from each replicated plot undergoing each treatment in both experiments for quantitative chemical determinations of total and soluble iron and manganese in the meristematic tissue of the leaves. Fifteen leaves were taken from 15 plants chosen at random from the 45 plants in each replicated plot. The active or largest leaf of each plant was selected for this purpose (2). The procedure followed for preparing the leaf samples for chemical analyses was practically the same as explained earlier (2).

\section{Method of ANALyses}

To digest the ground leaf-tissue samples for determination of total iron and manganese the procedure described in a previous paper (2) was used. Iron was determined by the Saywell and Cunningham orthophenanthroline method (13), while manganese was determined according to the periodate method of Peech (9) using a Coleman spectrophotometer model 14.

The procedure explained earlier (2) was used for determinations of soluble iron and manganese in the leaf-tissue fractions.

\section{Experiments at Palo Blanco, Arecibo}

\section{GROWTH OF PLANTS UNDERGOING VARIOUS TREATMENTS}

During the course of the experiments it was observed that the pineapple plants from native slips made as good growth as those from Cuban slips. However, the plants from Cuban slips looked stockier and occupied somewhat more lateral space than those from native slips, which, on the other hand, tended to be slender and taller. No difference was noted in any individuals of the two groups of plants which could be attributed to lime or iron spray treatments. In other words, plants in unlimed plots made as good growth as plants in limed plots, while plants which received 2 iron sprays made as good growth and were as green as those which received 4 .

${ }^{6}$ As ammonia $\left(\mathrm{NH}_{3}\right)$. 
EFFECT OF TREATMENTS ON YIELDS-PLANT CROP

The yield of the pineapple plants for the plant crop in the Arecibo experiment are presented in table 1 , which also shows the evaluation of the statistical significance of the yield data as a result of treatments. It is clear that the pineapple plants from native slips were superior in production either at the 5- or 1-percent level to those from Cuban slips.

The partition of the treatment sum of squares into their component parts indicated that differences in source of slips affected fruit yields in a

TABLE 1.-Yield of pineapple plants developed from native and Cuban slips in Bayamón silty clay at Palo Blanco, Arecibo

[Plant and ratoon crops, 1948-49]

\begin{tabular}{|c|c|c|c|c|}
\hline \multirow{3}{*}{ Treatments } & \multicolumn{3}{|c|}{ Plant crop ${ }^{1}$} & \multirow{3}{*}{$\begin{array}{l}\text { Ratoon crop, } \\
\text { yield per } \\
\text { acre }\end{array}$} \\
\hline & \multirow{2}{*}{$\begin{array}{l}\text { Yield per } \\
\text { acre }\end{array}$} & \multicolumn{2}{|c|}{ Outyielded at- } & \\
\hline & & $\begin{array}{c}5 \text {-percent } \\
\text { level }\end{array}$ & $\begin{array}{c}\text { 1-percent } \\
\text { level }\end{array}$ & \\
\hline & Tons & & & Tons \\
\hline \multirow{2}{*}{\multicolumn{5}{|c|}{ 1. Plants from native slips, limed, 2}} \\
\hline & 22.28 & 7 & $5,6,8$ & 22.82 \\
\hline 2. Plants from native slips, limed, 4 & & & & \\
\hline iron sprays $\ldots \ldots \ldots \ldots \ldots \ldots \ldots$ & 20.76 & - & - & 21.54 \\
\hline \multicolumn{5}{|l|}{ 3. Plants from native slips, not limed, } \\
\hline 2 iron sprays $\ldots \ldots \ldots \ldots \ldots \ldots \ldots$ & 21.55 & 6 & 5,8 & 24.13 \\
\hline \multicolumn{5}{|l|}{ 4. Plants from native slips, not limed, } \\
\hline 5. Plants from Cuban slips, limed, 2 & 21.19 & 5,8 & - & 23.26 \\
\hline 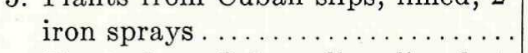 & 18.80 & - & - & 23.12 \\
\hline \multicolumn{5}{|l|}{ 6. Plants from Cuban slips, limed, 4} \\
\hline \multicolumn{4}{|l|}{$\begin{array}{l}\text { 7. Plants from Cuban slips, not } \\
\text { limed, } 2 \text { iron sprays............. }\end{array}$} & 24.18 \\
\hline \multirow{2}{*}{\multicolumn{5}{|c|}{$\begin{array}{l}\text { 8. Plants from Cuban slips, not } \\
\text { limed } 4 \text { iron sprays. }\end{array}$}} \\
\hline & 18.80 & 一 & 一 & 22.25 \\
\hline
\end{tabular}

${ }^{1}$ Least significant difference between mean yields at the 5-percent level, 2.00 tons; at the 1-percent level, 2.70 tons.

highly significant way and had no significant interaction with any of the other treatments (table 2). It was apparent that plants from native slips produced significantly more than those from Cuban slips. On the other hand, neither lime nor iron spray treatments had any significant effect on the yield of the plant crop.

RESULTS OF CHEMICAL ANALYSES OF LEAF-TISSUE FRACTIONS

The data for the determinations of total and soluble iron and manganese in the meristematic tissue of the active leaves analyzed for the plant 
crop are presented in table 3 . In order to find out whether there was any relation between leaf-tissue contents of soluble iron and manganese and yield, a covariance analyses was made. The results showed a highly significant difference between sources of slips even after eliminating the effects of the tissue contents of soluble iron and manganese on yield, indi-

TABLE 2.-Statistical analysis showing the partition of treatment sum of squares of deviations of fruit yields into main effects and interactions, Arecibo experiment

[Plant and ratoon crops, 1948-49]

\begin{tabular}{l|l|c|c|c}
\hline Source main factors & $\begin{array}{c}\text { Degrees of } \\
\text { freedom }\end{array}$ & $\begin{array}{c}\text { Sum of } \\
\text { squares }\end{array}$ & Variance & $F$ value $^{1}$ \\
\hline
\end{tabular}

\begin{tabular}{|c|c|c|c|c|}
\hline \multicolumn{5}{|c|}{ Plant crop } \\
\hline Treatments:............... & 7 & 1.6433 & & \\
\hline 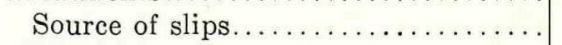 & 1 & 1.4400 & 1.4400 & $22.61 * *$ \\
\hline Lime $\ldots \ldots \ldots \ldots \ldots \ldots \ldots \ldots$ & 1 & .0110 & .0110 & 0.17 \\
\hline Iron $\ldots \ldots \ldots \ldots \ldots \ldots \ldots \ldots \ldots$ & 1 & .1000 & .1000 & 1.57 \\
\hline \multicolumn{5}{|l|}{ First order interactions: } \\
\hline Source of slips $\mathrm{x}$ lime... & 1 & 0 & 0 & 0 \\
\hline Source of slips $\mathrm{x}$ iron .......... & & 0 & 0 & 0 \\
\hline Lime $x$ iron $\ldots \ldots \ldots \ldots \ldots \ldots \ldots$ & 1 & 0 & 0 & 0 \\
\hline \multicolumn{5}{|l|}{ Second order interaction: } \\
\hline Source of slips $\mathrm{x}$ lime $\mathrm{x}$ iron . & 1 & .0923 & .0923 & 1.45 \\
\hline Error $\ldots \ldots \ldots \ldots \ldots \ldots \ldots \ldots \ldots \ldots$ & 28 & 1.7841 & .0637 & \\
\hline \multicolumn{5}{|c|}{ Ratoon crop } \\
\hline Treatments:..... & 7 & $1,508.37$ & & \\
\hline 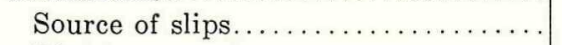 & 1 & 7.20 & 7.20 & 0.01 \\
\hline Lime ......................... & 1 & 455.70 & 455.70 & .51 \\
\hline Iron $\ldots \ldots \ldots \ldots \ldots \ldots \ldots \ldots$ & 1 & 697.20 & 697.20 & .78 \\
\hline \multicolumn{5}{|l|}{ First order interactions: } \\
\hline Source of slips $\mathrm{x}$ lime.......... & 1 & 189.70 & 189.70 & .21 \\
\hline Source of slips $x$ iron ............... & 1 & 2.10 & 2.10 & .002 \\
\hline Lime $\mathrm{x}$ iron $\ldots \ldots \ldots \ldots \ldots \ldots \ldots \ldots$ & 1 & 938.00 & 938.00 & .04 \\
\hline \multicolumn{5}{|l|}{ Second order interaction: } \\
\hline Source of slips $\mathrm{x}$ lime $\mathrm{x}$ iron ......... & 1 & 118.97 & 118.97 & .13 \\
\hline 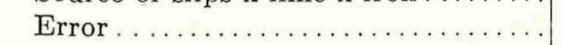 & 28 & $25,062.25$ & 895.08 & \\
\hline
\end{tabular}

${ }^{1}$ One asterisk indicates significance, two asterisks high significance in this and later tables.

cating thereby no evidence of a definite trend with respect to these elements in the plant tissue analyzed and yield of pineapple plants undergoing the various treatments.

\section{EFFECT OF TREATMENTS ON YIELDS-RATOON CROP}

The statistical analysis of the yield data for the ratoon crop presented in table 1 indicate that there were no significant differences between yields produced by plants from the two kinds of slips undergoing the various 
treatments. No significant yield differences were obtained which could be attributed to any of the source of slips, lime, or iron sprays (table 2). Contrary to expectations the experimental results presented for both plant and ratoon crops point to the fact that plants from native slips were

TABLE 3.-Total and soluble iron and manganese content of meristematic tissue of active leaves of pineapple plants developed from native and Cuban slips in

Bayamón silty clay at Palo Blanco, Arecibo

[Plant and ratoon crops-1948-49]

\begin{tabular}{|c|c|c|c|c|c|}
\hline Treatments & $\begin{array}{l}\text { Total } \\
\text { iron }\end{array}$ & \begin{tabular}{|c|} 
Solu- \\
ble \\
iron
\end{tabular} & \begin{tabular}{|c|} 
Total \\
manga- \\
nese
\end{tabular} & $\left|\begin{array}{c}\text { Soluble } \\
\text { manga- } \\
\text { nese }\end{array}\right|$ & $\begin{array}{c}\text { Ratio } \\
\mathrm{Fe} / \mathrm{Mn}\end{array}$ \\
\hline
\end{tabular}

Plant crop

1. Plants from native slips, limed, 2 iron sprays.

2. Plants from native slips, limed, 4 iron sprays.

3. Plants from native slips, not limed, 2 iron

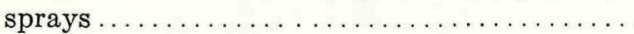

4. Plants from native slips, not limed, 4 iron

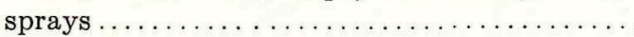

5. Plants from Cuban slips, limed, 2 iron sprays

6. Plants from Cuban slips, limed, 4 iron sprays.

7. Plants from Cuban slips, not limed, 2 iron sprays.

\begin{tabular}{|r|r|r|r|r}
\hline P.p.m. & P.p.m. & P.p.m. & P.p.m. & \multicolumn{1}{c}{ Soluble } \\
351 & 63 & 1006 & 166 & $0.50: 1$ \\
324 & 145 & 676 & 661 & $.22: 1$ \\
& & & & \\
252 & 58 & 902 & 289 & $.20: 1$ \\
& & & & \\
312 & 124 & 1448 & 1085 & $.11: 1$ \\
828 & 485 & 430 & 260 & $1.80: 1$ \\
651 & 450 & 553 & 326 & $1.38: 1$ \\
& & & & \\
469 & 133 & 128 & 102 & $1.30: 1$ \\
& & & & \\
540 & 150 & - & - & - \\
\hline
\end{tabular}

Ratoon crop

1. Plants from native slips, limed, 2 iron sprays. .

2. Plants from native slips, limed, 4 iron sprays.

3. Plants from native slips, not limed, 2 iron

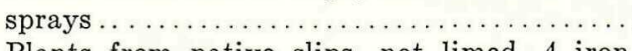

4. Plants from native slips, not limed, 4 iron

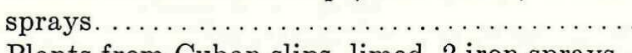

5. Plants from Cuban slips, limed, 2 iron sprays.

6. Plants from Cuban slips, limed, 4 iron sprays.

7. Plants from Cuban slips, not limed, 2 iron

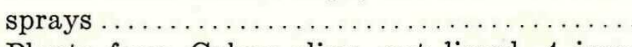

8. Plants from Cuban slips, not limed, 4 iron sprays.

\begin{tabular}{r|r|r|r|r}
201 & 68 & 840 & 544 & $0.13: 1$ \\
140 & 15 & 510 & 253 & $.06: 1$ \\
254 & 67 & 930 & 632 & $.11: 1$ \\
& & & & \\
166 & 66 & 810 & 552 & $.12: 1$ \\
140 & 27 & 690 & 473 & $.06: 1$ \\
88 & 56 & 810 & 494 & $.11: 1$ \\
114 & 50 & 780 & 416 & $.12: 1$ \\
114 & 19 & 870 & 485 & $.04: 1$ \\
\hline
\end{tabular}

either significantly superior or equal in production to plants from Cuban slips. This point will be considered in the discussion.

\section{RESULTS OF CHEMICAL ANALYSES OF LEAF-TISSUE FRACTIONS}

Table 3 reports also the iron and manganese contents, both total and soluble, of the meristematic tissue of active leaves of the pineapple plants 
undergoing the various treatments. Again, for the ratoon crop, the analyses of covariance indicated no conclusive evidence of a definite relation between the elements iron and manganese in the leaf-tissue samples and fruit production.

\section{Experiments at Experiment Station Farm, Rio Piedras}

\section{GROWTH OF PLANTS UNDERGOING VARIOUS TREATMENTS}

Similar results were obtained with respect to plant growth at Río Piedras as at Arecibo. However, irrespective of treatments and kind of slip, the plants of the Arecibo experiment made better growth than those at Río

TABLE 4.-Yield of pineapple plants developed from native and Cuban slips in Fajardo clay at Experiment Station Farm, Rio Piedras

[Plant and ratoon crops-1948-49]

\begin{tabular}{|c|c|c|c|c|c|}
\hline & Plan & crop 1 & Rat & oon cror & \\
\hline Treatments & & $\begin{array}{c}\text { Out- } \\
\text { yielded }\end{array}$ & & Outy & Ided \\
\hline & $\begin{array}{l}\text { per } \\
\text { acre }\end{array}$ & $\begin{array}{l}\text { at } 5 \text {-per- } \\
\text { cent } \\
\text { level }\end{array}$ & $\begin{array}{c}\text { per } \\
\text { acre }\end{array}$ & $\begin{array}{c}5 \text {-per- } \\
\text { cent } \\
\text { level }\end{array}$ & $\begin{array}{c}1-\text { per- } \\
\text { cent } \\
\text { level }\end{array}$ \\
\hline & To & & Tons & & \\
\hline 1. Plants from native slips, limed, 2 iron sprays. & 18.74 & 一 & 10.59 & - & - \\
\hline 2. Plants from native slips, limed, 4 iron sprays. & 18.98 & - & 8.27 & - & - \\
\hline 4. Plants from native slips, not limed, 4 iron & 17.33 & - & 11.08 & - & - \\
\hline 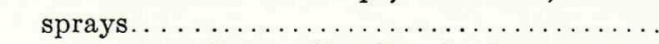 & 20.02 & - & 13.76 & 1,6 & 2 \\
\hline 5. Plants from Cuban slips, limed, 2 iron sprays. & 19.41 & - & 11.25 & - & - \\
\hline $\begin{array}{l}\text { 6. Plants from Cuban slips, limed, } 4 \text { iron sprays. } \\
\text { 7. Plants from Cuban slips, not limed, } 2 \text { iron }\end{array}$ & 19.72 & - & 10.53 & - & - \\
\hline 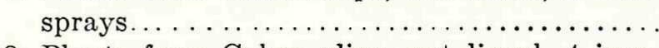 & 21.98 & 3 & 11.75 & 2 & - \\
\hline $\begin{array}{l}\text { 8. Plants from Cuban slips, not limed, } 4 \text { iron } \\
\text { sprays } \ldots \ldots \ldots \ldots \ldots \ldots \ldots \ldots \ldots \ldots\end{array}$ & 20.57 & 一 & 13.00 & - & 2 \\
\hline
\end{tabular}

${ }^{1}$ Least significant difference between yields at the 5-percent level, 3.47 tons.

${ }^{2}$ Least significant difference between yields at the 5-percent level, 3.10 tons; at the 1-percent level, 4.18 tons.

Piedras. One factor which might have contributed to this difference in vegetative growth is the productivity index of the soils, which is much higher for the Bayamón silty clay of Arecibo than for the Fajardo clay of Río Piedras (12).

\section{EFFECT OF TREATMENTS ON FRUIT YIELDS-PLANT CROP}

Table 4 reports the yield data in tons of fruit per acre for the plant crop. Contrary to the Arecibo plant-crop experiment, the statistical analyses of the yield data indicated that the experiment in itself was not significant, 
since the $F$ value for the experiment was 1.31 , as compared to an $F$ value of 2.36 required for odds of $19: 1$. In spite of this, treatment 7 (plants from Cuban slips, not limed, 2 iron sprays) surpassed treatment 3 (plants from native slips, not limed, 2 iron sprays) in production at the 5-percent

TABLE 5.-Statistical analysis showing the partition of treatment sum of squares of deviations of fruit yields into main effects and interactions, Rio Piedras experiment

[Plant and ratoon crops, 1948-49]

\begin{tabular}{|c|c|c|c|c|}
\hline Source, main factors & $\left|\begin{array}{c}\text { Degrees } \\
\text { of free- } \\
\text { dom }^{1}\end{array}\right|$ & $\begin{array}{l}\text { Sum of } \\
\text { squares }\end{array}$ & Variance & $F$ value \\
\hline \multicolumn{5}{|l|}{ Plant crop } \\
\hline Treatments. & 7 & 1.7563 & .2509 & 1.31 \\
\hline Source of slips.. & 1 & .7343 & .7343 & 3.84 \\
\hline 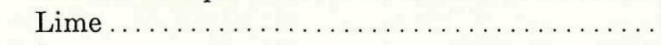 & 1 & .1488 & .1488 & .78 \\
\hline Iron $\ldots \ldots \ldots \ldots \ldots \ldots \ldots \ldots \ldots \ldots \ldots \ldots$ & 1 & .0547 & .0547 & .29 \\
\hline \multicolumn{5}{|l|}{ First order interactions } \\
\hline Source of slips $\mathrm{x}$ lime. & 1 & .2496 & .2496 & 1.30 \\
\hline Source of slips $\mathrm{x}$ iron.... & 1 & .2690 & .2690 & 1.41 \\
\hline Lime $\mathrm{x}$ iron $\ldots \ldots \ldots \ldots \ldots$ & 1 & .0072 & .0072 & .04 \\
\hline \multicolumn{5}{|l|}{ Second order interactions } \\
\hline Source of slips $\mathrm{x}$ lime $\mathrm{x}$ iron ... & 1 & .2927 & .2927 & 1.53 \\
\hline 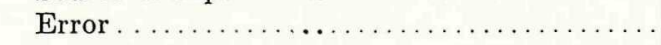 & 27 & 5.1668 & .1914 & \\
\hline
\end{tabular}

\begin{tabular}{|c|c|c|c|c|}
\hline \multicolumn{5}{|l|}{ Ratoon crop } \\
\hline Treatments. . & 7 & $5,324.05$ & & \\
\hline Source of slips............... & 1 & 288.37 & 288.37 & .94 \\
\hline 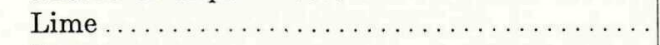 & 1 & $2,785.56$ & $2,785.56$ & $9.06^{* *}$ \\
\hline Iron $\ldots \ldots \ldots \ldots \ldots \ldots \ldots \ldots \ldots \ldots \ldots \ldots \ldots$ & 1 & 31.68 & 31.68 & .10 \\
\hline \multicolumn{5}{|l|}{ First order interactions } \\
\hline Source of slips $\mathrm{x}$ lime. & 1 & 326.05 & 326.05 & 1.06 \\
\hline Source of slips $\mathrm{x}$ iron. & 1 & .20 & .20 & 0 \\
\hline Lime $x$ iron ............ & 1 & $1,602.77$ & $1,602.77$ & $5.21^{*}$ \\
\hline \multicolumn{5}{|l|}{ Second order interactions } \\
\hline Source of slips $\mathrm{x}$ lime $\mathrm{x}$ iron .......... & 1 & 289.42 & 289.42 & .94 \\
\hline 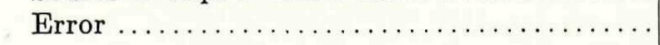 & 27 & $8,306.98$ & 307.67 & \\
\hline
\end{tabular}

${ }^{1}$ Number of degrees of freedom for error reduced by one because of a missing observation.

level. This significant difference should be taken as chance and not as conclusive since, as mentioned above, the experiment was not significant. In synthesis, there was no difference between the plants from native slips and those from Cuban slips when under corresponding treatments. Obviously no significant yield differences were found which could be attributed to source of slips, lime, or iron sprays (table 5). 


\section{RESULTS OF CHEMICAL ANALYSES OF LEAF-TISSUE FRACTIONS}

Table 6 presents the results of quantitative chemical determinations of total and soluble iron and manganese in the meristematic tissue of active leaves analyzed for the plant crop. The results of the covariance analyses showed no definite relation between the contents of iron and manganese in the plant tissue analyzed and yield of pineapples. It can

TABLE 6.-Total and soluble iron and manganese content of meristematic tissue of active leaves of pineapple plants developed from native and Cuban slips in Fajardo clay at Experiment Station Farm, Rio Piedras

[Plant and ratoon crops-1948-49]

\begin{tabular}{cc|c|c|c|c}
\hline Treatments & & Total & $\begin{array}{c}\text { Solu- } \\
\text { ble } \\
\text { iron }\end{array}$ & $\begin{array}{c}\text { Total } \\
\text { iron- } \\
\text { ga- } \\
\text { galu- } \\
\text { nese } \\
\text { man- } \\
\text { ga- } \\
\text { nese }\end{array}$ & $\begin{array}{c}\text { Ratio } \\
\text { Fe/Mn }\end{array}$ \\
\hline
\end{tabular}

Plant crop

\begin{tabular}{l|r|r|r|r|c}
\hline & P.p.m. & P.p.m. & P.p.m. & P.p.m. & Soluble \\
1. Plants from native slips, limed, 2 iron sprays ... & 150 & 64 & 32 & 0 & - \\
2. Plants from native slips, limed, 4 iron sprays .... & 140 & 99 & 47 & 44 & $2.25: 1$ \\
3. Plants from native slips, not limed, 2 iron sprays.. & 37 & 9 & 3 & 3 & $3.00: 1$ \\
4. Plants from native slips, not limed, 4 iron sprays.. & 30 & 6 & 3 & 2 & $3.00: 1$ \\
5. Plants from Cuban slips, limed, 2 iron sprays .... & 248 & 115 & 79 & 115 & $1.00: 1$ \\
6. Plants from Cuban slips, limed, 4 iron sprays .... & 273 & 99 & 0 & 0 & - \\
7. Plants from Cuban slips, not limed, 2 iron sprays.. & 11 & 27 & 2 & 2 & $13.50: 1$ \\
8. Plants from Cuban slips, not limed, 4 iron sprays.. & 5 & 26 & 2 & 0 & - \\
\hline
\end{tabular}

\section{Ratoon crop}

1. Plants from native slips, limed, 2 iron sprays ....

2. Plants from native slips, limed, 4 iron sprays....

3. Plants from native slips, not limed, 2 iron sprays.

4. Plants from native slips, not limed, 4 iron sprays. .

5. Plants from Cuban slips, limed, 2 iron sprays...

6. Plants from Cuban slips, limed, 4 iron sprays....

7. Plants from Cuban slips, not limed, 2 iron sprays.
8. Plants from Cuban slips, not limed, 4 iron sprays.

\begin{tabular}{|r|r|r|r|r}
210 & 30 & 180 & 116 & $0.26: 1$ \\
210 & 68 & 90 & 53 & $1.28: 1$ \\
193 & 9 & 270 & 85 & $.11: 1$ \\
149 & 11 & 180 & 86 & $.13: 1$ \\
245 & 53 & 240 & 206 & $.26: 1$ \\
210 & 17 & 60 & 39 & $.44: 1$ \\
210 & 52 & 210 & 116 & $.45: 1$ \\
374 & 205 & 60 & 18 & $11.40: 1$ \\
\end{tabular}

be seen from table 6 that treatments 2 and 5 show a high concentration of total and soluble manganese in relation to the other treatments, but there is no explainable reason for this variation at the present time.

\section{EFFECTS OF TREATMENTS ON FRUIT YIELDS-RATOON CROP}

The yield data for the ratoon plants which underwent the different treatments are presented also in table 4 . The results of the evaluation of 
the statistical significance of the yield differences that may be attributed to treatment effect appear in the same table. It is evident that, irrespective of iron sprays, either native or Cuban plants grown in unlimed soils produced significantly more at the 5- or 1-percent level than similar plants on limed soils.

The low production of the ratoon crop in this case must be attributed to competition of grasses and weeds with the pineapple plants, it having been impossible to cultivate the soil because of intermittent heavy rains for several months. Otherwise it is logical to assume that under normal weather conditions, as was the case for the Arecibo ratoon crop, the yields would have been equal to, if not higher than, the yields of the plant crop.

To find what influence, if any, treatment components and their corresponding interactions had on yields of the ratoon crops, a statistical analysis was made of the yield data with respect to source of slips, lime, and iron sprays, a summary of which is shown in table 5. The partition of the treatment sum of squares into their component parts indicated that neither source of slips nor iron sprays were important. However, the use of lime was detrimental to yield in a highly significant way, as is evident in the data presented in table 4. Similar results were obtained by Pennock and Hernández on the use of lime and the production of pineapple plants $(2,3,10)$.

\section{RESULTS OF CHEMICAL ANALYSES OF LEAF-TISSUE FRACTIONS}

The results of the total and soluble iron and manganese determinations in the plant tissue of the ratoon plants analyzed are presented in table 6 . As with these same treatments in the ratoon plants of the Arecibo experiment, no significant relation was found between yield and iron and manganese in the leaf fractions analyzed.

Summing up the results presented thus far for both plant and ratoon crops in both the Arecibo and Río Piedras experiments, it may be said that pineapple plants from native slips were either superior or equal in fruit production to pineapple plants from Cuban slips. Moreover, no conclusive evidence was obtained which could explain variations in the production of pineapple plants on the basis of iron and manganese contents of the plant tissue analyzed.

\section{Additional Experiments}

To continue the studies on the apparent "run-down" or "degeneration" of the Cuban slips in the second generation, and to find out whether the condition occurred there, additional experiments were begun in the same localities where the previous experiments were carried on-that is, at Palo Blanco, Arecibo, and at the Experiment Station Farm at Río Piedras. 
They were planted in the same type of soils. The Arecibo experiment was planted on September 30, 1948, while the Río Piedras experiment was planted on January 21, 1951.

The pineapple plants in both of these experiments developed from slips obtained from the plants of the plant-crop experiments established for the first time in 1946 with native and Cuban slips. The same treatments were used for each group of slips as for the experiments previously reported. However, the number of replications per treatment was increased from

TABLE 7.-Yield of pineapple plants developed from native and Cuban slips obtained from the plant-crop experiments at Palo Blanco, Arecibo, and Experiment Station Farm at Rio Piedras established in 1946

\begin{tabular}{|c|c|c|c|c|}
\hline \multirow{3}{*}{ Treatments } & \multirow{3}{*}{$\begin{array}{l}\text { Plant crop } \\
\text { of Arecibo: } \\
\text { Yield per } \\
\text { acre }\end{array}$} & \multicolumn{3}{|c|}{ Plant crop of Río Piedras } \\
\hline & & \multirow{2}{*}{$\begin{array}{c}\text { Yield per } \\
\text { acre }\end{array}$} & \multicolumn{2}{|c|}{ Outyielded at ${ }^{1}-$} \\
\hline & & & $\begin{array}{c}5-\text { percent } \\
\text { level }\end{array}$ & $\begin{array}{c}\text { 1-percent } \\
\text { level }\end{array}$ \\
\hline 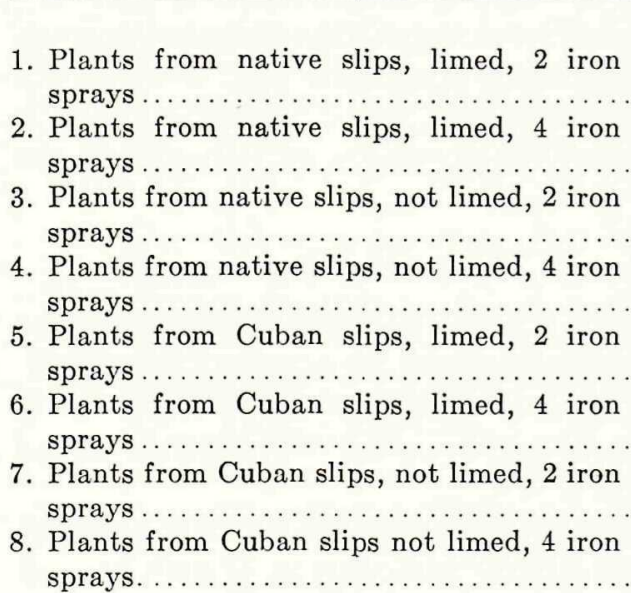 & $\begin{array}{r}9.92 \\
11.14 \\
9.74 \\
12.06\end{array}$ & $\begin{array}{l}9.37 \\
6.12 \\
7.78\end{array}$ & - & $1,2,5$ \\
\hline
\end{tabular}

${ }^{1}$ Least significant difference between yields at the 5 -percent level, 1.49 tons; at the 1-percent level, 2.01 tons.

5 to 6 in the Arecibo experiment only. Similar procedures were followed for setting up the experiments, fertilizing the plants, and collecting and preparing leaf samples for chemical analyses. The same methods of analyses were used for determination of total and soluble iron and manganese.

The plants of both experiments were acetylene treated on December 5, 1949, and February 1950 respectively, and were harvested on May and June, and July and August, respectively. Since only a plant crop was harvested from each experiment, the results of both will be considered together. 


\section{GROWTH OF PLANTS UNDERGOING VARIOUS TREATMENTS}

During the course of the experiments it was noted that growth of the plants, both from native and Cuban slips, was not as good as that of plants in the first experiments. Vegetative growth was less, as evidenced

TABLE 8.-Statistical analysis showing the partition of treatment sum of squares of deviations of fruit yields into main effects and interactions, Arecibo and

Rio Piedras experiments

[Plant crop]

\begin{tabular}{|c|c|c|c|c|}
\hline Source main factors & $\begin{array}{l}\text { Degrees } \\
\text { of } \\
\text { freedom }\end{array}$ & $\begin{array}{c}\text { Sum } \\
\text { of } \\
\text { squares }\end{array}$ & Variance & $F$ value \\
\hline \multicolumn{5}{|l|}{ Arecibo experiment } \\
\hline Treatments. & 7 & 1.1582 & & \\
\hline Source of slips. & 1 & .1365 & 0.1365 & 0.6900 \\
\hline $\operatorname{Lime} \ldots \ldots \ldots \ldots \ldots \ldots \ldots$ & 1 & .3169 & .3169 & 1.6021 \\
\hline Iron...$\ldots \ldots \ldots \ldots \ldots \ldots$ & 1 & .5002 & .5002 & 2.5280 \\
\hline \multicolumn{5}{|l|}{ First order interactions } \\
\hline Source of slips $\mathrm{x}$ lime.. & 1 & .0420 & .0420 & .2123 \\
\hline Source of slips $x$ iron.... & 1 & .0015 & .0015 & .0076 \\
\hline Lime $x$ iron $\ldots \ldots \ldots \ldots$ & 1 & .0675 & .0675 & .3412 \\
\hline \multicolumn{5}{|l|}{ Second order interactions } \\
\hline Source of slips $\mathrm{x}$ lime $\mathrm{x}$ iron. & 1 & 0.0936 & .0936 & .4732 \\
\hline Error.................... & 35 & 6.7115 & .1978 & \\
\hline
\end{tabular}

Rio Pedras experiment

\begin{tabular}{|c|c|c|c|c|}
\hline Treatments. & 7 & 0.9275 & & \\
\hline Source of slips.. & 1 & .0384 & 0.0384 & 1.0847 \\
\hline Lime .......... & 1 & .6150 & .6150 & $17.37^{* *}$ \\
\hline Iron............... & 1 & .0563 & .0563 & 1.5903 \\
\hline \multicolumn{5}{|l|}{ First order interactions } \\
\hline Source of slips $\mathrm{x}$ lime. & 1 & .0062 & .0062 & .1751 \\
\hline Sour & 1 & .0047 & .0047 & .1327 \\
\hline Lime $\mathrm{x}$ iron & 1 & .0077 & .0077 & .2175 \\
\hline \multicolumn{5}{|l|}{ Second order interaction } \\
\hline Source of slips $\mathrm{x}$ lime $\mathrm{x}$ iron & 1 & .1992 & .1992 & $5.63^{*}$ \\
\hline Error..... & 28 & .9911 & .0354 & \\
\hline
\end{tabular}

by height and less profuse development of plants. There was a general tendency for the plants to be rather slender, this condition being more pronounced in those resulting from native slips than in the plants from Cuban slips. In the Río Piedras experiment growth was more depressed, especially in the lime-treated plants of both groups of slips, as compared with the unlimed plants. This seemed to indicate that lime was detrimental to plant growth and consequently to production, as will be shown later. 


\section{EFFECT OF TREATMENTS ON YIELDS}

Table 7 reports the yield from the pineapple plants which underwent treatment in the Arecibo and Río Piedras experiments. The results of the evaluation of the statistical significance of the yield differences between the treatments in the Arecibo experiment indicated that there was no significant difference between the yields of the two types of plants undergoing corresponding treatments. In other words, plants developed from native slips yielded as heavily as plants from Cuban slips. The results were similar to those obtained for the ratoon crop of the Arecibo experiment already reported, in which no significant differences in yield were obtained which could be attributed to source of slips, lime applications, or iron sprays (table 8).

The striking fact brought out by the yield data of the Río Piedras experiment (table 7) is that unlimed plants from both native and Cuban slips yielded significantly better at the 5- or 1-percent level than plants grown in soil that received lime applications.

The partition of the treatment sum of squares into their component parts indicated that neither source of slips nor iron sprays affected fruit yields. On the other hand, lime affected fruit yields adversely in a highly significant way (table 8). Thus lime was detrimental to the production of pineapple plants, as was pointed out in discussing the yield data presented in table 8 for the Río Piedras experiment.

\section{Discussion}

The yield data obtained in the first set of the 1946 experiments demonstrated that plants from native slips produced significantly more than or as well as plants from Cuban slips. Growers believe that plants from native slips produce less, since they claim that plants from Cuban slips, which have been planted in the Island for two or three generations, produce considerably less than plants from such slips when planted for the first time in the Island. Thus, there seems to be a sort of contradiction between the growers' views and our first experimental results. However, the results of the statistical analyses of treatment components (source of slips, lime, and iron sprays) indicated, at least for the plant crop of the Arecibo experiment, that difference in the source of slips affected yields in a highly significant way, but had no significant interaction with any of the other treatments. In the Río Piedras experiments the source of slip had no significant effect, which indicated that native slips were as good as the Cuban. Hence, a possible explanation for obtaining significantly higher yields, or as good yields, with native as with Cuban slips is that the native slips used in these experiments, although having being planted 
in Puerto Rico for two generations, had for some reason either a higher or as good vigor as the Cuban slips.

When yields of the plant crop in the second set of experiments are considered (experiments established with slips obtained from the plants of the first experiments set up in 1946) it is evident that there was quite a reduction in yields as compared to those of the first plant-crop experiments. This was true for pineapple plants from both native and Cuban slips. In fact, it was not possible to obtain slips of proper size for future plantings. Contrary to the first case, these results accord with the pineapple growers' view in that pineapple production, and consequently the obtaining of good slips for future plantings, declines as pineapple plantings are continued on the same sites. However, these results, and others that have been presented in this paper, do not show that the apparent "degeneration" or "run-down" of pineapple slips which result in low production result from an unfavorable balance of iron and manganese in the pineapple plant adversely affecting its normal metabolism.

The nonbeneficial effect or detrimental effect of lime on yields in the experiments discussed, which confirm previous findings $(2,3,10)$, plus the ineffectiveness of iron sprays, in addition to the lack of relationship between the tissue contents of iron and manganese in the pineapple plants and their production, all tend to strengthen the assumption that factors other than iron and manganese are responsible for loss of vigor of pineapple slips and consequent progressively lower yields of pineapples in Puerto Rico. Moreover, the fact that significantly lower yields were obtained from plants in limed soils than from those in unlimed soils (approximate $\mathrm{pH}$ of 5), wherein manganese is supposed to be quite active, strongly suggests that factors other than iron-manganese relationships adversely affect pineapple production.

We believe, however, that the apparent "degeneration" or "run-down" of pineapple slips might be attributed in part to unfavorable changes brought about in the soil as a result of present agricultural practices. If these could be modified in some respects, it should be possible to obtain pineapple slips of uniform and adequate size, weight, and vigor to produce good fruit yields for several years. For example, lime should be applied to only those pineapple soils which require this amendment to raise the $\mathrm{pH}$ to 4.5 or 5.0 for optimum production of pineapples, or to soils that have been so intensively cultivated that there is need of this material to supply the plants with the calcium necessary for normal metabolism. The use of filter press cake offers great potentialities for increasing the yield of pineapples $(2,3)$. These agricultural practices together with others which might contribute not only to increased yields but also to the production of healthy pineapple slips of proper planting size, should be put into 
practice. In this way it would be possible to obtain good fruit yields and good planting material for the years following.

\section{ConClusion}

The ineffectiveness of iron sprays to pineapple plants, plus the nonbeneficial or detrimental effect of lime applications to pineapple soils, in addition to the lack of relationship between quantitative chemical analyses for both total and soluble iron and manganese in the pineapple plant tissue and yields, point to the possibility that factors other than iron and manganese may be responsible for the apparent "degeneration" of pineapple slips and consequent lowered fruit yields. Therefore, the apparent "degeneration" of pineapple slips should be considered from other angles and no longer as a result of iron-manganese relationships in the soil and in the plant.

\section{SUMMARY}

Pineapple experiments were carried on using imported Cuban slips and native slips with the object of investigating the apparent "degeneration" of slips. The suggestion that this apparent "degeneration" of slips might result from a nutritional derangement produced by an unfavorable balance of iron and manganese that was more severe in the plants developed from native slips, and resulted in a more marked chlorosis than in the plants developed from Cuban slips, led to studies of iron-manganese relationships in the pineapple plant under field conditions as the initial point of attack on this problem.

Cuban as well as native slips were planted in untreated soil and in soil which received calcium carbonate as ordinarily applied by pineapple growers to control manganese in the soil. In addition, the plants which developed from each group of slips received either 2 or 4 iron sprays; the purpose was to find out which spray procedure was best. The experimental data from the various experiments may be summarized as follows:

1. Pineapple plants from native slips were either superior or equal in production to those developed from Cuban slips. This was true for both plant and ratoon crops.

2. The use of lime was either nonbeneficial or detrimental to yields of pineapples.

3. No significant yield differences were found whether 2 or 4 iron sprays were applied to the plants.

4. Similar results were obtained both with respect to yields and to the use of lime and iron sprays in later experiments with slips obtained from the plants of the first plant-crop experiments.

5 . The yields obtained in the plant crop of the later experiments were considerably less than those from the first plant-crop experiments. This 
was true for both native and Cuban plants. It also accords with the pineapple growers' view that pineapple production, and consequently the obtaining of good slips for future plantings, declines when pineapple plantings are long continued on the same sites.

6. No relationship was found between the soluble iron and manganese in the plant tissue analyzed and yields of pineapples. This suggests that factors other than iron and manganese may be responsible for the apparent "degeneration" or loss of vigor of pineapple slips which is reflected in low yields.

\section{Literature Cited}

1. Bureau of Agriculture Economy, Department of Agriculture, Government of Puerto Rico, 1951.

2. Hernández-Medina, E., The beneficial effect of filter press cake on pineapple growth, development, and production, I, Effect on the plant crop, Jour. of Agric. Univ. P. R., 36(3) July 1952.

3. Hernández-Medina, E., The beneficial effect of filter press cake on pineapple growth, development, and production, II, Effect on the ratoon crop, Jour. of Agric. Univ. P. R., 36(3) July 1952.

4. Hopkins, E. F., Pagán, V., and Ramírez, Silva F. J., Iron and manganese in relation to plant growth and its importance in Puerto Rico, Jour. of Agric. Univ. P. R., 28(2) 43-101, April 1944.

5. Johnson, M. O., The spraying of yellow pineapple plants on manganese soils with iron sulphate solution, Hawaii Agric. Exp. Sta., Press Bul. 51, 1916.

6. Manganese as a cause of the depression of the assimilation of iron by pineapple plants, Jour. Ind. and Eng. Chem., 9 47-49, 1917.

7. Manganese chlorosis of pineapple: its cause and control, Hawaii Agric. Exp. Sta. Bul. 52, 1924.

8. Kelley, W. P., The influence of manganese in the growth of pineapples, Hawaii Agric. Exp. Sta., Press Bul. 23, 1908.

9. Peech, M., Determination of exchangeable bases in soils, Ind. and Eng. Chem. Anal., 13(6) 436-441, June 1941.

10. Pennock, W., Field response of Red-Spanish pineapples to nitrogen, calcium, iron and soil pH, Jour. of Agric. Univ. P. R., 33(1) 1-26, January 1949.

11. Riera, A., Laboratory recommendation of lime to an acid soil checks with expected pH changes, Jour. of Agric. Univ. P. R., 30(3) 184-185, July 1946.

12. Roberts, R. C. et al., Soil Survey of Puerto Rico, U.S.D.A. Bureau of Plant Industry in coop. with the Univ. of P. R., Agric. Expt. Sta., Series 1936, No. 8, 503 p., issued January 1942.

13. Saywell, L. G., and Cunningham, B. B., Determination of iron-colorimetric oo-phenanthroline method, Ind. and Eng. Chem., 9 67-69, 1937.

14. Schappelle, N. A., Clorosis de hierro causada por exceso en manganeso; Estación Experimental Agrícola, Río Piedras. Puerto Rico, Informe Bienal 1938-39, 1939-40: 15 .

15. - Fertilizer studies with pineapples in Puerto Rico, Jour. of Agric. Univ. P. R., 26(3) 41-60, July 1943.

16. - Iron chlorosis caused by excessive manganese, Univ. of P. R. Agric. Expt. Sta., Annual Report 1939-40, 57-59, 1941.

17. Wilcox, E. V., and Kelley, W. P., The effect of manganese on pineapple plants and the ripening of the pineapple fruit, Hawaii Agric. Exp. Sta. Bul. 28, 1912. 